\title{
The Legal Framework of Referendum in the Iranian Constitutional Context
}

\begin{abstract}
In democratic regimes, the participation of citizens in the enforcement of political power constitutes the keystone of the legitimacy of sovereignty. Allowing and valuing the popular will in the political management of a country is necessary for the continuation of the legitimacy of sovereignty. Hence, political systems are still exploring the methods of establishing direct democracy in parallel to representative democracy. Referendum is a form of establishing direct democracy that is based on public votes on political and legal affairs. The legal organization of different kinds of direct democracy is explained in the constitutions. Among the methods of direct democracy, only referendums on the amendment of the constitution, political referendums, and legislative referendums have been recognized in the Constitution of the Islamic Republic of Iran. Although a referendum on the establishment of the Islamic Republic political system and a referendum on the amendment of the Constitution have been held in the legal history of Iran, no legislative referendum has been conducted so far. Senior state officials may propose a referendum and referendums can be held on special and critically important occasions. Regarding the theocratic nature of the Iranian political system, the validity of referendums is contingent upon non-contradiction between the subject of the referendum and the principles of Islamic law. This article explores the legal dimensions of conducting referendums in the Iranian constitutional context with a descriptive-analytical approach.
\end{abstract}

Key words: direct democracy, referendum, Islamic Republic of Iran, constitution.

\section{Introduction}

0 ne of the fundamental principles of democracy is public participation in the political management of society. This principle can be realized directly or indirectly. Direct participation in enacting law is more compatible with the spirit of national sovereignty than other forms of legislation; however, since it is difficult to turn to public votes in densely populated countries, the indirect participation of the people is prioritized in constitutions and resorting to a popular vote is restricted to the critical issues (Katozian, 2006, p. 87).

Direct democracy is a form of governance in which people are directly engaged in running sovereignty (Hashemi, 2011, p. 229). Over time, representative democracies developed for different reasons, but direct democracy is still available and is resorted to on critical issues, albeit as an exception. In semi-direct democracy, which is a combination of direct and representative democracies, both citizens and representatives exercise political power in parallel (Hashemi, 2011, p. 229). Referendums, petitions, citizens' initiatives and recall are said to be some forms of such democracy (Baigi, 2017). Referendums are an instrument of semi-direct democracy (Morel, 2017, p. 27), allowing the public to take part in making political decisions in their societies (Ghamami, 2011, 
p. 257). Referendums mean asking for a popular vote and having the people's participation to clarify if a law is required or not, to determine the form and content of ordinary laws or the constitutional one (Ghazi, 1994, pp. 372-373). In constitutions, referendums should be distinguished as a key source of legislation, based on which legislators can make the necessary decisions.

The forms, manners and legal effects of referendums depend on the political system in which they are run (Rahimi, 2004, p. 149). A referendum usually offers a choice to be accepted or rejected; however, in rare cases, it gives the electorate the choice among multiple options. A two-option referendum happens when the legislator, prior to passing a law, turns to a public vote. This type of referendum is purely advisory, and if the people agree to the subject of the referendum, it is not considered binding in itself, but binds the legislature to have the necessary proposition enacted. However, if a final draft of a parliamentary bill or a constitution is submitted to the people to be approved, the referendum is then said to be an approval vote and is considered binding (Hashemi, 2015, pp. 232-233). Moreover, in a multiple choice referendum, the citizens are offered various choices. For instance, in 1945, when France was released from occupation by the Germany, three options were submitted to the people to make a decision on: first, the return to the constitution of the Third Republic (1876); second, establishing a new parliament with limited powers; and third, setting up a constituent assembly to pass a new constitution. In the end, people voted for the third choice, the result of which was the constitution of the Fourth Republic (1946) (Hashemi, 2015, p. 233).

There is no consensus among jurists if a referendum is a democratic method or not (Morel, 2012, p. 508). Most legal scholars believe that any decision made in parliament is the result of deliberation and interaction, so they prioritize this over referendums. To them, the former method is a reflection of the tendencies that a society may have already agreed on. In the latter method, the decisions made are the final product of momentary orientations and exciting speeches, and it is easier to deceive the citizens than the elites. Moreover, the popularity of the political authority which has called for the referendum may affect the result of the vote, as a rule (Ghazi, 1994, pp. 373-374).

But the supporters of referendums consider them an instrument that, on the one hand, limits the power of absolute parliamentarianism and, on the other one, guarantees the rights of citizens. To them, a referendum is a means by which democracy can be protected. By this, people gain the right to be engaged in making decisions on critical issues. Those who favor referendums presume that ordinary people possess an accurate and deep understanding of political and legal issues; however, they, know what a certain policy may result in, what in consequence may finally affect the overall plan of a government (Ghazi, 1994, p. 374).

An ideal and valid democratic system is one that recognizes all the methods of the establishment of direct democracy, thereby broadening public participation in the political management of society in parallel to the establishment of representative democracy. In practice, contemporary political systems have recognized only some of the methods of the establishment of direct democracy in the constitutions or ordinary laws. The political system of the Islamic Republic of Iran is no exception, and has recognized only referendums on the revision of the constitution and legislative referendums. There is, in fact, a lack of consensus on political referendums among Iranian 
jurists. Some jurists advocate its recognition in the constitution while some others disapprove of it.

The establishment of direct democracy is linked to the type of political system. From the theoretical point of view, democratic systems have the potential for the legal identification of different methods of conducting referendums and minimizing the constraints upon the establishment of direct democracy. However, in non-democratic political systems, conducting different forms of direct democracy is limited, and direct democracy mainly serves as a means of granting approval to the existing political system or prior decisions to grant them public approval and political legitimacy.

The political system of the Islamic Republic of Iran is a theocratic system. However, the role of the public in legislation is recognized both indirectly (i.e., the election of the representatives in the Islamic Consultative Assembly) and directly (i.e., through legislative referendums on crucial issues) (Rostami, 2008, p. 180). In addition, public opinion is also a determinant of referendums on the revision of the constitution. Due to the nature of the Iranian political system, the process of referendum enforcement should be examined. This article, using a descriptive and analytical approach, is focused on different legal dimensions of referendums in the Iranian constitutional context.

\section{Historical Background of Referendums}

Although Iranians, due to the Constitutional Revolution, were familiar with such concepts as democracy and elections, the first Iranian Constitution (1906) and its supplementary document (1907) were silent on the subject of referendums. The only reference could be found in Article 26 of the supplementary document, where the legitimacy of the Legislative, the Executive, and the Judiciary is left to the nation. In Article 27, a law is said to have been passed if it has been ratified in both the parliament (Majlis) and the Senate, and finally signed by the king. Perhaps one reason why referendums were not proposed in the constitution was that the constitutional designers were afraid that the king might use a referendum to change the new constitutional monarchy back to the former absolute one (Madani, 1995, p. 387). Although the constitution was silent about referendums, they took place several times. The first was launched on August 3, 1953 and August 10, 1953 to decide on the dissolution of the $17^{\text {th }}$ parliament. This was the first experience of Iranian citizens in exercising direct democracy.

The second referendum took place to decide on the White Revolution (the Shah and People's Revolution plan). The Shah (the king), while explaining elements of the revolution said, "the principles that I, as the king of the country and head of the state, offer directly to popular vote are the following: Revocation of the peasantry as a result of land reforms, nationalization of forests and pastures, sale of some state-owned factories to finance land reforms, profit sharing scheme for workers in industry, amendment of the Electoral Laws (in order to recognize the right to vote of women), establishment of literacy corps in order to establish public and mandatory education" (Ghamami, 2011, p. 271). On January 26, 1963, a referendum was called to vote on the six principles of the White Revolution, in which 5,598,711 people voted for the reforms and 4,115 voted against them (Amin, 2005, p. 4). 
Following the Islamic revolution in Iran, this country has experienced three referendums. The first one was held on April 30/31, 1979 in which the citizens were asked to vote on changing the constitutional monarchy regime to an Islamic republic. Most of the political groups and parties supported the referendum but there was no consensus on the forms of the republic. The religious leaders and clergymen insisted on establishing an Islamic republic. The left-wing groups were asking for a people's democratic republic. The nationalists were also looking for an absolute republic. Finally, Ayatollah Khomeini called for a referendum to say "Yes" or "No" to the Islamic republic. Here, the other forms of republic were ignored (Amin, 2005, pp. 65-66). According to the figures released by the interim government, 2,282,120, people voted for the plan while 140,066 voted against it. In other words, $98.2 \%$ of the eligible citizens said "Yes" to the Islamic republic, and only $1.8 \%$ said "No" to it.

Following the approval of the political system of the Islamic Republic of Iran, the Assembly of Experts prepared the first draft of the constitution, the final text of which was offered to popular vote in December 1979. When the constitution was approved in 1979, referendums, as a method of passing legislation, were formally recognized in chapter 5 under the title of The Right of National Sovereignty and its Ensuing Powers. A second referendum was held on December 2/3, 1979. Reports released by the authorities said $15,578,956$ people voted on the constitution.

In August 1989, after reevaluating the constitution, it was decided to have the final draft approved through a referendum. In it 16,428,976 people voted on the revised constitution, in which 15,976,685 people supported it (Partovi, 1999, p. 87). Although legislative referendums are recognized in the Iranian Constitution, the country has not experienced any referendums yet. Iranian citizens have gone through referendums only to vote on establishing the Islamic republic, to approve the constitution and to vote on reevaluating it.

\section{Types of Referendum}

Of all types of referendum, only the legislative referendum and constitutional revision referendum are recognized in the constitution. The constitution has an ambiguous stand on the legal position of political referendums. Different types of referendums are discussed in the following sections.

\section{Legislative Referendum}

When legislation is put to a public vote, it is called a legislative referendum, which is held mainly on crucial issues (Hashemi, 2015, p. 72). Article 59 of the Constitution of the Islamic Republic of Iran states the following:

\footnotetext{
"In extremely important economic, political, social, and cultural conditions, the legislative authority may hold referendums and directly seek a public vote. The request for a public vote has to be approved by two-thirds of the representatives in the Islamic Consultative Assembly.”
} 
Furthermore, Article 36 of the Referendum Act of the Islamic Republic of Iran, which was passed on June 25, 1989 by the Islamic Consultative Assembly, states what follows:

"A referendum is held provided that it is proposed by the president or a hundred representatives in the Islamic Consultative Assembly, and is approved by at least two-thirds of the representatives in the Islamic Consultative Assembly."

Although the president and representatives in the Islamic Consultative Assembly are the direct representatives of the public, the failure to identify the legal mechanism for initiating a public referendum has been criticized. This is because any proposal made by the aforesaid authorities is discretionary, and they can hold a legislative referendum at any point in time. However, the Constitution of the Islamic Republic of Iran was passed over forty years ago, and yet no legislative referendum has been conducted to date. Furthermore, the key reasons for holding referendums have not been identified, and no example has even been given in legal instruments.

Since a legislative referendum has to be passed with a yes/no approach, it reflects the importance of referendu issue and makes the Islamic Consultative Assembly conduct the legislation procedure for the subject of the referendum. To wit, although any proposal for a referendum put forward by the president or a hundred representatives of the Islamic Consultative Assembly is arbitrary, the legislative authority is obliged to present a detailed legislation plan and carry out the legal procedures by virtue of Article 59 of the Constitution. Yes/no referendums are not in line with informed and thoughtful democracy due to the citizens' unawareness of the details of the legal plan.

If the ability to propose a referendum is confined only to the political authorities, it may lead to undesirable results. For example, if the political authorities determine the subject and date of a referendum directly or indirectly, such a referendum cannot guarantee democracy. In addition, the fact that the ability to propose a referendum is monopolized by the political authorities and citizens have no right to call for one is also criticized. This may change a referendum into an undesirable plebiscite. The reason for this is that if the political authorities enjoy the right to propose a referendum, they will be more empowered to get closer to their objectives, so it is recommended to set up an electoral supervisory board to monitor referendum plans impartially (Khosravi, Ameri, Moghaddasi, 2019, p. 19).

A legislative referendum is as valuable as ordinary laws with the approval of the Guardian Council, while the laws resulting from a referendum can be changed with the approval of the ordinary law. However, since the public directly voices their opinion on the referendum subject and referendums are held only on special and critically important occasions, the legislative system should respect the direct majority vote (Katozian, 2006, p. 91).

\section{Political Referendum}

A political referendum refers to a process wherein the president wins public trust on a subject by making extraordinary political decisions based on a majority vote. In the Constitution of the Islamic Republic of Iran, there is no clear reason set out for calling political referendums (Hashemi, 2015, p. 73). However, according to paragraph three of Article 110, it is one of the powers of the Supreme Leader to demand a referendum with- 
out determining its type. Hence, it is concluded that the Supreme Leader can not only call for a referendum on the revision of the constitution but can also win public trust to take some political and legal decisions based on a public vote.

Some jurists oppose the recognition of political referendums in the constitution. They argue that paragraph three of Article 110, which introduces the referendum order as one of the Supreme Leader's powers, was added in the 1989 revision of the Constitution and it did not exist before that date. They believe this paragraph was added to the 1989 Constitution because one can be initiated by the Supreme Leader using Article 177. Therefore, the referendum order mentioned in paragraph 3 of Article 110 is rooted in Article 177, which refers to the referendum on the revision of the constitution (Pour Abbas, 2005, p. 22).

Nevertheless, regarding the place of the Supreme Leader's status in the Constitution of the Islamic Republic of Iran, it seems the referendum listed as one of the Supreme Leader's powers is independent of the referendum order mentioned in the Constitution. However, the Supreme Leader has not demanded such a referendum so far. A political referendum has a political nature and solely mirrors the agreement or disagreement of the public with the referendum subject and their trust in the political system. Thus, such a decision by citizens is not required to be approved by the Guardian Council.

\section{Referendum for Constitutional Revision}

The political systems leave the approval of the final revision of the constitution to a popular vote to demonstrate that such reevaluation is run in a democratic way (Alizadeh, Nasiri, 2012, p. 34). The constitution stands at the top of the Iranian legal system. This position is related to the fact that the constitution is a document establishing a political system, setting up a government structure, confining the power of political authorities, recognizing the citizen's rights and preserving such rights. However, the constitution cannot be confined to a particular period and is not eternal. It needs to be revised from time to time due to various social changes. The fundamental value of the constitution and its priority over other regulations in the hierarchy of legal sources requires having the constitution revised in a legal procedure distinguished from ordinary legislation. The constitution is revised within a specified framework. During this procedure, some articles may change while other may be removed. It is also possible to have some rules supplemented (Taghizadeh, Fadayi Jooybari, 2013, pp. 187-188). When a general or partial amendment of the constitution is offered to the public vote, it is called a constitutional referendum.

According to Iranian Constitutional Law, the revision of the constitution is initiated by the leader as the supreme authority of the country. The leader, after consultation with the Expediency Council, which is the only official reference for consulting the leadership, in a statement to the president, determines the necessary revisions to the constitution. This proposal is then submitted to the Council for Reevaluating the Constitution. After the leader approves and signs the draft of the Council, the proceedings must be put to a public vote and approved by an absolute majority of the participants in a referendum. The leader faces no limitations to disapprove of the legislation of the Council for 
Reevaluating the Constitution, and consequently he may stop the procedure of revision. Of course, the leadership cannot make any changes to this draft directly. The leader supervises the draft of the Council only to preserve the Islamic nature of the system. The final draft cannot be offered to a popular vote unless it is approved and signed by the leadership. The final draft signed and approved by the leader is not presented to the public unless he orders a referendum to be held (Taghizadeh, Fadayi Jooybari, 2013, pp. 200-201).

The final draft of the Council for Reevaluating the Constitution must be approved by an absolute majority of the participants in a referendum. The request to appeal to a public vote does not need to be approved by two-thirds of the representatives of the Islamic Consultative Assembly. The quorum for a legislative referendum is dealt with under Article 59 of the Constitution.

The result of a referendum on the revision of the constitution gives a direct consequences to the regulations in constitutions. The revised provisions subsequently repeal the contradictory provisions in the constitution, or some provisions are annexed to the constitution. To wit, the revised provisions are as valuable as the constitution, but their validity is contingent on the approval of their conformity with Islamic law. As stated, the Islamic jurists in the Guardian Council decide on this matter at their discretion.

\section{Process of Enforcement of Referendums}

The Islamic Republic of Iran's Referendum Act, which was passed on June 25, 1989 by the Islamic Consultative Assembly, determines the method of holding referendums. This act was only enforced for the revision of the constitution in July 1989 and it has not been enforced since. Seemingly, this Act applies to legislative referendums on the revision of the constitution.

According to Article 36 of this Act, "a referendum is held provided that it is proposed by the president or a hundred representatives of the Islamic Consultative Assembly and is approved by at least two-thirds of the representatives of the Islamic Consultative Assembly." By Article 1 of this Act, a referendum is conducted as a yes/no referendum. According to Article 14 of the Referendum Act, voters must have Iranian nationality, must be aged 16 (or older), and must be of sound mind. In all Iranian election laws, the minimum voter age is 18 , but the minimum age in a referendum is 16 . Lowering the voter age increases the number of eligible voters and influences the quantity of given votes and result of the referendum. Regarding being of sound mind, the legislator has not set out any criteria. Therefore, according to Islamic legal maxim, it is assumed the voters are of sound mind unless proven otherwise by compelling evidence.

Articles 3, 4 and 6 of this Act stipulate that a referendum is conducted directly and publicly using the secret ballot method. The Ministry of the Interior is responsible for conducting the elections and determines and announces the referendum date in collaboration with the Guardian Council. Votes are cast inside and outside the country on a single day within a ten-hour period. The voting period can be extended if necessary. The Minister of the Interior determines whether the voting period can be extended at his discretion. Votes have to be cast on a public holiday. 
The Islamic Republic of Iran Broadcasting Corporation is obliged to broadcast public information programs about the referendum, as well as all the notices issued and selected by the Minister of the Interior or the selected representatives of the Guardian Council, on national or local TV of the Islamic Republic of Iran Broadcasting Corporation (Article 7).

In addition, according to Article 10 of the Referendum Act, votes are voided in the following cases: the ballot box not sealed; more votes than voting cards; votes cast by underage voters; votes by voters who use the IDs of deceased or non-Iranian persons; votes gained through deception and fraud; votes cast with others' IDs or fake IDs; votes cast using the IDs of absent voters; votes lacking the referendum seal; votes gained by threats; and votes cast using illegal ballots. However, votes that are purchased or sold are voided with the approval of the control board or its representative, but they are tallied, reported, and attached to the election protocols.

The following actions are considered to be crimes, and the committers face punishments set out by law: exchange of votes; fraud in ballots or election protocols; threats or corruption in a referendum; voting with fake IDs; voting with others' IDs; voting more than once; interrupting the referendum; increasing or decreasing the number of votes or voting cards; cheating in the ballot polling and counting; casting votes with the IDs of persons that are not present; recommendations by the polling place officials or any other person for casting the ballot in a certain ballot box; changing, converting, faking, stealing, or destroying election documents and papers (including ballots, protocols, telexes, telegrams); opening or breaking the lock of the ballots' storage place or the seals of ballot boxes without legal permission; modifying or destroying referendum documents without legal permission; intimidating voters or members of the polling place, with or without a gun, during a referendum; intervening in a referendum with a fake document or in any illegal way (Article 12).

\section{Monitoring Referendums}

The Guardian Council supervises and controls the elections of all democratic entities except for the elections of the Islamic Councils of cities and villages. The Guardian Council also supervises all referendums by ensuring the validity of the referendum process and ensuring the lack of deviation from Islamic law and the Constitution. The scope of supervision by the Guardian Council includes legislative referendums and referendums on the revision of the constitution. The legitimacy of the supervision by the Guardian Council over the elections and legal acts originates from Article 4 of the Constitution of the Islamic Republic of Iran. ${ }^{1}$ As regards the lack of consensus over the scope of the Guardian Council's supervision over different types of referendums, it could be stated that one of the Iranian jurists believes supervision by the Guardian Council does not include referendums on the revision of the constitution, and it is only limited to the

${ }^{1}$ Article 4: "All civic, penal, financial, economic, administrative, cultural, military, political, and other laws and regulations must be based on Islamic criteria. This principle governs all the articles of the constitution, and other laws and regulations. The determination of such compatibility is left to the Islamic jurists of the Guardian Council." 
legislative referendums referred to in Article 59 of the Constitution (Esmaeeli, 2003, p. 36). But regarding Articles 4 and 99 of the Constitution and Article 37 of the Referendum Act, the scope of supervision by the Guardian Council includes all referendums held within the framework of the constitution.

Thus, the Council has the power to cancel a referendum to be held even if it has already been approved by the president or one hundred representatives of the Assembly. Moreover, even if the authenticity of a referendum is already approved, the Guardian Council can rule out the results. In other words, the Guardian Council, in practice, has an effective role in all procedures of a referendum. At the beginning, the Guardian Council may decide if a request for holding a referendum must be appealed or not, which seems justified. The validity of the referendum is also left to the Council, which appears reasonable; however, it is not compatible with the logic of democracy if the Guardian Council comments on the results of the public vote, while the result has already been approved. The Guardian Council must secure the nation's rights determined in the constitution, including approval of the results of a referendum. Otherwise, unbiased observers may consider the Council's performance a violation of the rule of law, while ignoring the right to public participation.

\section{Signing of a Referendum}

According to Article 123 of the Constitution, "the president is obliged to sign the Islamic Consultative Assembly's acts or the result of a referendum following the legal procedures and service of process and must submit it to the authorities for enforcement."

In this regard, Article 27 of the Referendum Act of the Islamic Republic of Iran ordains as follows:

"The Guardian Council communicates its opinion to the president within one week, or at most ten days (if necessary), after the communication of the referendum result and the president communicates the result to the Ministry of the Interior after signing the documents. Afterward, the Minister of the Interior informs the public of the referendum result through the mass media."

As regards signing Islamic Consultative Assembly acts, and the result of a referendum, Article 1 of the Civil Code (amended on November 5, 1991) states the following:

"Acts passed by the Islamic Consultative Assembly and the referendum results are communicated to the president following the completion of the legal procedures. The president shall sign the results within five days, communicate them to the officials, and issue the order for their announcement. The official journal is also obliged to publish the results within 72 hours of their communication. If the president refuses to sign or communicate the results within the period identified in this article, the official journal is obliged to publish the results within 72 hours at the command of the head of the Islamic Consultative Assembly."

Hence, the president's refusal does not prevent the recognition of the referendum. However, the president's refusal to sign the result is considered a violation of his legal 
duties and the Islamic Consultative Assembly may interpellate him for this action. The Supreme Court may also prosecute the president for his failure to fulfill one of his legal obligations.

\section{The Legal Constraints on Referendums}

According to the Constitution of the Islamic Republic of Iran, there are constraints on the time and subject of referendums. The legal constraints on referendums are, therefore, discussed in this section.

In every constitution, some of the fundamental principles of the political system are non-revisable, based on the constitution, because the revision of the constitution shall not result in the elimination of the fundamental goals and values of the political system. To wit, the continuation and survival of the governing political system call for the protection of its fundamental goals and values from change (Tagizadeh, Fadayi Jooybari, 2013, p. 204; Aslani, Rahmanian, 2017, p. 46).

The Iranian political system is a theocracy, which is established through public elections. Therefore, the validity of direct or indirect legislation in the religious system of the Islamic Republic of Iran is contingent upon a lack of deviation from the Islamic laws. Any difference between legal acts and Islamic laws or the constitution results in the nullification of those acts under the supervision of the Guardian Council. In addition to the aforesaid constraints on referendums, similar to legislation, the Islamic Consultative Assembly shall not violate the unchangeable acts of the constitution. Moreover, referendums conducted by violating the limitations specified in Article 177 are invalid. ${ }^{2}$

Because of the importance of the constitution, any revision of the constitution must be put to a public vote, in peace and away from any social and political tumult and turbulence. According to Article 177 of the Constitution, the revision of specific provisions of the constitution is not permitted under any circumstances. In Article 132 of the Constitution, the revision of the constitution is, however, permitted under specific circumstances. It says when the duties and powers of the president are assigned to the first deputy or another person appointed by the leadership, no attempt can be made to review the constitution. The reason for such a provision is that when all authority of the president is assigned to someone else, the society may face political and social turbulences in the president's absence, which, in turn, may affect the referendum. Thus, a referendum is postponed until a new president is elected and the country is at peace. If the same situation happens to the leadership, a referendum can be initiated after it is proposed by the Leadership Council and is, then, approved by three-fourths of the members of the Expediency Council.

${ }^{2}$ The last paragraph of Article 177 stipulates that: "It is impossible to change the content of the articles which concern the Islamic nature of the system; establishment of all the laws and regulations on the bases of Islamic criteria and the faith and aims of the Islamic Republic of Iran; the form of the government as a republic; the sovereignty of the command [of God] and religious leadership of the community [of believers]; administration of affairs with reliance on general referendums, and the official religion and ideology of Iran.” 


\section{Conclusion}

Despite the criticisms of referendums, political systems still resort to them on important occasions. Besides, the legal organization of referendum is defined in constitutions or ordinary laws. In the Iranian legal system, the first constitution had no position on referendums, but several referendums were held in practice. Following the Islamic revolution, the political system of the Islamic Republic of Iran was put to a referendum. Once again, with the approval of the political system by a majority vote, the draft of the Constitution of the Islamic Republic of Iran was put to a referendum. Thereafter, legislative referendums were recognized in Article 59 of the Constitution for the first time in the new political system of Iran by a majority vote of Iranians. After ten years of the enforcement of the Constitution, the revision of the constitution was mentioned in 1989 in the revised constitution and the recognition of the revision of the constitution was considered to be contingent upon a majority vote. Once again it was approved by the majority of the voters taking part in the referendum.

Although public participation in the legislative process is recognized by the Constitution, no legislative referendum has been conducted so far in the Iranian political system. The reliance of the Iranian political system on Islam and the theocratic nature of this political system are also worth noting. To wit, a referendum on the revision of the constitution can be initiated by the Supreme Leader and lies within his power alone. Thus there is no legal mechanism for the citizens to initiate referendums. Islam plays a substantial role in the political and legal structure of the Islamic Republic of Iran, and public opinion is valid only if it is not contradictory to Islamic laws. Furthermore, the yes/no referendum approach limits the options. Hence, the political system should facilitate the adoption of all direct democracy methods by the public and increase public participation in the political management of society.

\section{Bibliography}

Alizadeh J. Nasiri S. (2012), Referendum in Iranian legal system, “Journal of Legal Thinkers”, no. 2.

Aslani F., Rahmanian A. (2017), The Irreversible Principles of the Constitution and the Examination of Their Validity, "Public Law", no. 17.

Biagi F. (2017), Plebiscite, in: Max Planck Encyclopedia of Comparative Constitutional Law, OUP.

Mohsen E. (2003), Referendum and Guard Council, "Methodology of Humanities", no. 36.

Papan-Matin F. (2014), The Constitution of the Islamic Republic of Iran (1989 Edition), Iranian Studies, $47: 1$.

Hashemi S. M. (2015), Constitutional Law of the Islamic Republic of Iran, vol. 2, Mizan Publication, Tehran.

Hashemi S. M. (2011), Constitutional Law and Political Institutes, Mizan Publication, Tehran.

Khosravi A., Ameri Z., Moghaddasi M. B. (2018), Legislative plebiscite: a manifestation of democracy in the realm of legislation, "Journal of Political Science Quarterly", no. 83.

Katozian N. (2006), Philosophy of Law, vol. 2, $3^{\text {rd }}$ edit., Enteshar Publication, Tehran.

Ghazi A. (1994), Constitutional Law and Political Institutes, vol. 1, University of Tehran publication, Tehran.

Ghamami M. M., (2011), Constitutional Law of the Islamic Republic of Iran, Center of the Islamic Revolution Documents Publication, Tehran. 
Morel L., Qvortrup M. (2017), Types of Referendums, Provisions and Practice at the National Level Worldwide, in: The Routledge Handbook to Referendums and Direct Democracy, eds. L. Morel, M. Qvortrup, Routledge.

Morel L. (2012), Referendum, in: The Oxford Handbook of Comparative Constitutional Law, eds. M. Rosenfeld, A. Sajó, Oxford University Press, Oxford.

Madani S. J. al-Din, (1995), The Constitutional Law and Political Institutes in Islamic Republic of Iran, $3^{\text {rd }}$ ed, Alameh Tabatabee Publication.

Pourabbas Y. (2005), Implementation Sovereignty with Direct Democracy Methods and its Application in the Islamic Republic of Iran, "Journal of Constitutional Law", no. 5.

Partovi K. (1999), Referendum in Iran, Jonge Danesh Pub, Tehran.

Rahimi I. (2004), The Referendum Status in Representative Democracies Regimes, "Kanoon Journal", no. 53 .

Rostami V., (2008), People's Participation in the Legislation in the Islamic Republic of Iran, "University of Tehran's Journal of Law", vol. 38, no. 1.

Taghizadeh J., Fadaei Jouibari M. (2013), An Investigation on the Revision of the constitution in Iranian Constitutional Law, "Journal of Legal Research's", no. 63.

The Referendum Act of the Islamic Republic of Iran (1989).

\section{Ramy prawne referendum w irańskim kontekście konstytucyjnym}

\section{Streszczenie}

W reżimach demokratycznych udział obywateli w egzekwowaniu władzy politycznej stanowi podstawę suwerenności. Zezwolenie i docenienie woli ludu w politycznym zarządzaniu krajem jest konieczne dla utrzymania legitymacji suwerenności. Dlatego systemy polityczne wciąż badają metody ustanowienia demokracji bezpośredniej równolegle $\mathrm{z}$ demokracją przedstawicielską. Referendum jest formą ustanowienia demokracji bezpośredniej opartej na głosowaniu publicznym w sprawach politycznych i prawnych. Prawna organizacja różnych rodzajów demokracji bezpośredniej jest wyjaśniona w konstytucjach. Wśród metod demokracji bezpośredniej tylko referenda w sprawie zmiany konstytucji, referendum polityczne i referendum legislacyjne zostały uznane w Konstytucji Islamskiej Republiki Iranu. Chociaż w prawnej historii Iranu odbyło się referendum w sprawie ustanowienia systemu politycznego Republiki Islamskiej i referendum w sprawie zmiany Konstytucji, jak dotąd nie przeprowadzono referendum legislacyjnego. Wyżsi urzędnicy państwowi mogą zaproponować referendum, a referenda mogą odbywać się w wyjątkowych i niezwykle ważnych sytuacjach. Jeśli chodzi o teokratyczny charakter irańskiego systemu politycznego, ważność referendum zależy od braku sprzeczności między przedmiotem referendum a zasadami prawa islamskiego. W tym artykule zbadano prawne wymiary przeprowadzania referendów w irańskim kontekście konstytucyjnym, stosując podejście opisowo-analityczne.

Słowa kluczowe: demokracja bezpośrednia, referendum, Islamska Republika Iranu, konstytucja 